\title{
The World Bank, support for universities, and asymmetrical power relations in international development
}

\author{
Christopher S. Collins $\cdot$ Robert A. Rhoads
}

Published online: 4 June 2009

(C) The Author(s) 2009. This article is published with open access at Springerlink.com

\begin{abstract}
This article examines the role of the World Bank in advancing higher education sectors in the developing world, considering in particular the increasing power and strength of a global knowledge-based economy. Given the powerful role that intergovernmental organizations such as the World Bank play in shaping global economic policies, the authors are concerned about how the Bank's policies and actions may limit knowledge generation and capacity building of universities in the developing world. Relatedly, the authors use case studies of the Bank's involvement in Thailand and Uganda to better understand the role it plays in producing and reproducing forms of global hegemony. The authors discuss hegemony in terms of neocolonialism and neoliberalism. Neocolonialism is described as forms of domination advanced by powerful nations and their institutions, while neoliberalism is understood as an economic ideology by which weaker nations may be brought into greater alignment with global trade initiatives.
\end{abstract}

Keywords Higher education · World Bank · Developing nations · International development $\cdot$ Knowledge economy

We must take stock of the nostalgia for empire, as well as the anger and resentment it provokes in those who were ruled, and we must try to look carefully and integrally at the culture that nurtured the sentiment, rationale, and above all the imagination of empire. Edward Said, Culture and Imperialism (1993, p. 12)

C. S. Collins $(\bowtie) \cdot$ R. A. Rhoads

Graduate School of Education and Information Studies, UCLA, 3141 Moore Hall,

Box \# 951521, Los Angeles, CA 90095-1521, USA

e-mail: christopher.s.collins@gmail.com

R. A. Rhoads

e-mail: rhoads@ucla.edu 


\section{Introduction}

The above quote from Edward Said's Culture and Imperialism is intended to frame the discussion that follows as we examine the role of the World Bank in supporting universities in the developing world. The project from which this paper derives initially sought to better understand the Bank's policies in terms of support for higher education in the developing world, and most specifically, whether or not evidence exists that reveals a shift in funding priorities. Reports from the Bank coming out at the beginning of the twenty-first century suggested that it had become more interested in supporting the development of universities, signaling somewhat of a policy shift from previous practice (World Bank 2000, 2002). This supposed shift seemed consistent with a growing understanding of the role universities play in knowledge development and human capacity building, given the strength of the global, new knowledge economy (Peters and Besley 2006; Rhoads and Torres 2006a, b; Slaughter and Rhoades 2004). But along the way toward pursuing our initial research question linked to funding priorities, other issues arose as the complexities of World Bank policies and the challenges of university development came into greater focus. Consequently, additional questions became central to our study. In particular, we wanted to better understand the role the Bank potentially plays in producing and/or reproducing global inequities through its higher education policies. Here, our thinking also came to be influenced by emerging research and growing criticism concerning the Bank's role in perpetuating the powerful status of the world's wealthiest nations, which also happen to be the nations with the greatest influence over World Bank policy making (Goldman 2005; Peet 2003; Santos 2006; Stiglitz 2002). And while emerging scholarship began to paint a more vivid portrait of the complicity of IGOs such as the World Bank in furthering global inequalities, little of this research employed empirically grounded analyzes of higher education policy making and the impact on developing nations.

In time, we came to center our concern about the relationship between the Bank and universities in the developing world on issues best described as neocolonial and neoliberal, the former conveying new forms of global hegemony advanced by powerful nations and their institutions, and the latter representing an economic ideology by which weaker nations may be brought into greater alignment with global trade initiatives. We see both ideas-neocolonialism and neoliberalism-as deriving to a great extent from the global economic interests of powerful nations like the United Kingdom and the United States, advanced most significantly in the 1980s by political leaders such as Margaret Thatcher ("Thatcherism") and Ronald Reagan ("Reaganism"), but continuing throughout the 1990s and into the present decade (Apple 2000; Hall and Jacques 1990; Morrow and Torres 2000; Torres and Rhoads 2006). Our focus on universities in particular reflects their importance to a rapidly changing, global economy and the role that knowledge production plays in situating a nation as part of this complex world order.

As our project evolved into a more critical analysis of the role of the Bank in university development, we became increasingly skeptical of claims that it was not duplicitous in the complex webs of power and global domination, but preferred putting our skepticism to the test by empirically examining actual cases. Consequently, this paper is the outcome of our effort to more critically examine the role of the Bank in advancing higher education sectors in the developing world. More specifically, we selected Uganda and Thailand as cases for study because both received World Bank support for university development in recent years, both struggle to strengthen their universities, both face difficult times economically speaking, and taken together, they offer an element of geographic diversity to our analysis (there are additional complexities to our sampling strategy that we explain in the 
methodology section of this paper). Theoretically speaking, we draw on scholarly work often described as postcolonial or neocolonial studies, as we seek to raise critical questions about the Bank's higher education loan programs and policy considerations within the context of two developing countries.

\section{International development, neocolonialism, and neoliberalism}

To understand the strategies behind the role development organizations such as the Bank play in contemporary times, it is helpful to briefly review the emergence and application of international development as a theoretical construct. A good starting point is to examine the basic paradigms governing international development, including the lingering effects of free-market modernization (also described as development theories) and dependency theories.

As a response to the failures of modernization theory, dependency theories arose in the 1960s and 1970s as part of a broad attempt to address ongoing world inequalities. Although serious questions have been raised over the years about whether or not dependency as a framework in fact constitutes a "theory" (Cardoso 1977), it nonetheless suggests a set of assumptions about world economic relations, including the idea that among nations there are haves and have nots, developed and developing, and core and periphery (and semiperiphery as well). From a dependency perspective, the structure of relationships among these two different categories of nations is believed to limit developing nations' economic growth and prosperity. However, within this broad school of thought, there have evolved major differences over how dependency frameworks are constructed and applied to make sense of world inequality, including differences linked to liberal reformism (Prebisch 1984), Marxism (Frank 1967), and world systems perspectives (Wallerstein 1979, 2004). Linking most dependency frameworks, however, and especially those of the liberal and Marxist variety, has been a pervasive criticism of being overly deterministic. This criticism ultimately contributed to the decline of dependency theories in favor of greater theoretical diversity.

Contemporary international development perspectives, while having some connections to earlier development and dependency frameworks, seek to complicate notions of developed and developing, core and periphery, while still recognizing structural conditions that may reproduce inequitable relationships within a world capitalist system. What is most interesting is the manner in which neoclassical economics has emerged to powerfully shape international development perspectives through an emphasis on trade liberalization as the ultimate solution to global economic inequality (Stiglitz 2002). For neoclassical economists, often described as "neoliberals" (given their fondness for "liberalizing" trade), developing nations are seen as potential beneficiaries of more open world markets, as organizations such as the World Trade Organization (WTO) advance more transparent trade policies, or so its supporters argue. But as Sidhu (2007) pointed out in a discussion of the "new developmentalism," decisions shaping global markets and free trade are not made in "open 'free' space," but instead are tied to "domestic and international power asymmetries" (p. 209). Sidhu went on to argue, "In this context, the grip of neoclassical economics is reasserted through circuits of geopolitical power and knowledge. Thus, the flexibilities and concessions provided by the WTO to developing countries ('special and different treatment') are effectively blunted by bilateral means, allowing more powerful economies to persuade weaker countries to adopt particular trade agendas that are less development friendly" (p. 209). Although Sidhu focused on the WTO's General 
Agreement on Trades and Services, including how transnational education might be governed as a service under GATS, what is important to take from this work in considering the role of the World Bank is the rise of a "new developmentalism," which Sidhu essentially defined as "the reconfiguration of trade liberalization as a developmental tool" (p. 203).

In general, the new developmentalism links economic development among poor nations to fuller participation in a global capitalist system. Much like the former dependency frameworks sought to understand economic inequality among nations from the perspective of global relations, constituted to a great extent during an age of imperialism and coinciding with the emergence and development of capitalism, today's dominant frameworks recognize transnational economic ties as being organized and maintained by late capitalism (Larrain 1989). Where arguably development policies of the past sought to retain an element of dependence, relationships among nations in an age of late capitalism are competitively structured in the name of global free trade.

In analyzing the new developmentalism, numerous critical scholars have focused on the role IGOs play in the developing world and how certain programs and policies seem to advance the interests of wealthier nations, while claiming to support developing nations. For example, Carroll (2006) raised important concerns about the new development agenda, or what he described as the post-Washington consensus (PWC) in action, when he identified how the World Bank's Kecamatan Development Program (KDP) in Indonesia served to plant the essential ideals and practices of a socio-institutional form of neoliberalism. A key goal of the project was a "realignment of economic, political and social institutions in a manner that supports the extension of the market into social life" (p. 3). For Carroll, what is most interesting about the Bank's KDP project is the way it sought to create fundamental change at the local level, bypassing national and regional governance structures through intense competitions targeting local villages. Packaged by the Bank as a "community empowerment/social protection project," the KDP emphasized the problems of poor governance and the related impact on market functionality. Thus, bad governance and limited markets were implicitly identified by the Bank as the source of poverty; accordingly, the solution was decentralization, privatization, and market liberalization-essentially, a stiff dose of neoliberalism was given at the local level so that it might better penetrate the social foundation of the nation from the ground up. Here, development solutions are consistent with Apple's (2000) critical discussion of neoliberalism, wherein anything that is understood as private "is necessarily good" and that which is seen as public "is necessarily bad" (p. 59).

From a broader perspective, many critics of dominant international development approaches and practices align to a great extent with scholars such as Harvey (2003), Chomsky (1999, 2003), and Said (1993). As Harvey (2003) noted in The New Imperialism, "If, for example, the US forces open capital markets around the world through the operations of the IMF (International Monetary Fund) and the WTO (World Trade Organization), it is because specific advantages are thought to accrue to US financial institutions" (p. 32). According to Harvey (2003), economic inequality among nations is not simply the outcome of unequal resources and geographic advantages, but "are produced by the uneven ways in which wealth and power themselves become highly concentrated in certain places by virtue of asymmetrical exchange relations" (p. 32). Decision making at the World Bank, for example, is tied to the financial contributions of donor countries, with the nations that give the most thus gaining greater control over loan programs and their conditions. 
Chomsky also raised concerns about the benefits that trade liberalization and the general ideological shift to neoliberalism have for the developing world. He described the basic rules of the neoliberal consensus as an array of principles designed by the United States and the international financial institutions it dominates: liberalize trade and finance, let markets set the price, end inflation, and privatize (Chomsky 2003). In Profit Over People: Neoliberalism and the Global Order, Chomsky (1999) pointed out that major industries within national economies such as Japan, the United Kingdom, and the United States developed with strong governmental support and complex forms of protectionism. For example, Chomsky maintained that the US steel, automotive, and semiconductor industries could not have effectively competed against coinciding Japanese industries without massive protectionism offered by the Reagan administration in the 1980s. But now, under the banner of neoliberalism, some of the very nations that achieved economic dominance, in part as a consequence of protectionism, together constitute a powerful driving force in calling for open global markets. Thus, for Chomsky, neoliberalism amounts to a free market doctrine "imposed on the defenseless," since in many cases industries in the developing world have grave difficulties competing with those of advanced nations (p. 34). In a very real sense, wealthier nations are saying to the developing world, "market discipline is good for you, but not for me, except for temporary advantage" (p. 34).

In Said's (1993) discussion of modern forms of empire building, he argued that the imperial struggle is not so much defined by the direct battle for land through violent military conquest (although military conflicts certainly continue to define elements of modern day imperialism), but instead contemporary forms of imperialism must be understood by a deeper and more complex struggle in which ideas, cultural forms, political maneuverings, and hegemonic policies define conquest. Along these lines, Said demonstrated that while powerful nations may have abandoned their former colonies in Africa and Asia, "They retained them not only as markets but as locales on the ideological map over which they continued to rule morally and intellectually" (p. 25). Said's point highlights the transition from colonialism operated by states and militarism to neocolonialism operated by international institutions acting in the interests of capitalism and competition favoring nations at the top of the global economic hierarchy. A question that arises here concerns the degree to which the World Bank and its higher education priorities contribute to a modern form of imperialism, or whether the Bank's policies in fact support economic development for the sake of the developing world?

As we look at the impact of the World Bank on universities in Uganda and Thailand, issues of dependence, past and present, are important to consider. For African countries like Uganda, Musazi (1986) maintained that they face problems of neocolonialism, because of the dependence on Western education, economics, and technology. Musazi posited that neocolonialism can function through "foreign aid programs, technical advisers, publishing firms, or other means. Dependency and neocolonialism are linked" (p. 325). Relatedly, some have argued that economic domination by the West is paralleled by academic dependence (e.g., African students studying British or French history). Alatas (1993), for example, referred to the phenomenon of mental captivity, where thinking is dominated by Western thought in an "imitative and uncritical manner" (p. 308). Concerns relating to academic dependence and mental captivity raise the importance of more indigenous approaches and the degree to which interventions in the developing world adequately account for the longstanding effects of dependency and/or colonialism.

Another concern arises out of the neoliberal pressure to privatize higher education as a sector and points to questions about the proper balance of public and private capital in support of universities in the developing world (Santos 2006). The new knowledge 
economy based on a neoliberal version of globalization is dominated by calls for private ownership and the accumulation of profit. In order to increase or liberalize private ownership, the role of public or state support must be diminished. The problem then is that without public support for autonomous and national universities (as in "nation-building universities"), acting for a broader social good that balances local and global pressures is arguably weakened (Ordorika and Pusser 2007; Pusser 2006; Rhoads and Torres 2006a, b; Santos 2006). Unfortunately, disinvestment in the public university has occurred in instances where the World Bank has concluded that higher education does not generate a sufficient return on investment (Santos 2006). In such an environment, higher education expansion is predicated on the view that private providers, often involving international parties, are to support such growth. This form of public disinvestment in the university may in the end permanently relegate developing nations to consumer status in the global knowledge economy. Disinvestment as a policy also ignores the ways in which public support has been crucial to advancing university science and technology in developed nations such as the United States (Geiger 1986, 1993). A question that arises in this project concerns the degree to which developing an adequate university structure for academic science falls on public versus private sources, and if both, what is the proper mix?

\section{Method}

This study was guided by the following research questions: (1) In what manner and form does the World Bank support higher education in the developing world? (2) What are the ideological underpinnings of the Bank's higher education initiatives in the developing world and what can be said about their impact on higher education in countries like Uganda and Thailand? (3) How do education officials in Uganda and Thailand view the World Bank's involvement in higher education in their respective nations? In seeking to address these research questions, we purposefully selected sites and individuals for the study that we believed would aid in understanding pertinent issues. Drawing from Arnold's (1970) strategy of dimensional sampling, which is used to strengthen the results of case study research when the number of cases is small, we searched for countries that might help us to analytically unravel key concerns or dimensions of our study. Key dimensions included receiving Bank support for higher education, having a history of international development as a recipient nation, and facing tough economic times in the present. Additionally, we wanted to pursue issues relating to previous colonization, but here we preferred to achieve some form of contrast, seeking a country that had previously been colonized and one that had not. Finally, we wanted to sample two different regions of the world to once again add an element of contrast.

Our research questions were examined through a three-phase research process. Phase 1 included an extensive review of key documents, policy reports, and loan contracts pertaining to the Bank's support for higher education in developing nations in general and Uganda and Thailand in particular. This also included a descriptive quantitative analysis of World Bank lending patterns for education and the sub-sector of higher education. Phase 2 of the project involved extensive semi-structured interviews with World Bank officials, conducted on-site at the Bank's headquarters in Washington, DC and over the telephone in a few instances. In Phase 3 of the project, case studies were conducted in both Uganda and Thailand. The case studies involved document analysis, observation, and semi-structured interviews with officials and policy makers affiliated with the respective Ministries of Education and higher education commissions and with Bank officials working in the 
respective countries. Additionally, several universities receiving Bank support were visited, allowing for interviews of faculty and staff involved in Bank-related initiatives. Included among the universities visited were Makerere University, Uganda Christian University, Kyambogo University, and Nkumba University in Uganda, and Chulalongkorn University, Thammasat University, Mahidol University, and the Rajamangala University of Technology in Thailand.

Interviews conducted on-site in Uganda and Thailand as well as those with Bank officials in DC were guided by data collection strategies delineated for case study and qualitative methods (Maxwell 1996; Yin 1989). In all, we conducted 39 semi-structured interviews, all of which were recorded and transcribed verbatim. Thirteen initial interviews were conducted with Bank officials (economists and education specialists) located in Washington DC and with former Bank employees, some of whom now work in academe. The remaining 26 interviews were conducted during separate three-week site visits to Uganda (12 interviews) and Thailand (14 interviews), completed during the summer of 2007. Although all three research questions framed the site visits to Uganda and Thailand, the third question, which focused on education officials' views of the Bank's involvement in higher education, was most pertinent to this phase. In each country the impact of their respective higher education loan or loans was assessed in the context of their borrowing history and their country-specific needs for higher education. Given that the primary thrust of the loans under study in both Uganda and Thailand were intended to support various science and technology initiatives at the university level, laboratories at various universities were toured and extensive field notes and photographs were taken.

Data analysis involved coding interview transcripts, field notes, key documents, and loan agreements, as well as analyzing World Bank trends in lending for education and its sub-sectors. The process of analysis was iterative and involved both deductive and inductive strategies. Although the study was divided into three phases, analysis was performed across the phases to compare emergent themes (Creswell 1998). The cross-phase analysis was not meant to create a meta-narrative, but to use the tensions that exist within an organization like the World Bank to further refine our understanding of development objectives. The various phases of the study helped to create multiple viewpoints on the topic across issues relating to higher education and knowledge for development.

\section{The World Bank and higher education funding}

To elucidate how education fits into the landscape of World Bank lending, Fig. 1 shows the increase of total new loan commitments during a 43-year period, in conjunction with the total new education loan commitments during the same time period in current dollars. Education commitments comprise a relatively small part of the overall landscape, and encompass about $8 \%$ of total lending during the last 3 years shown on the chart.

There are seven sub-sectors that comprise the total number of loans allocated for education and Fig. 2 shows the percentage of funds allotted to each in 2006.

During 2006, higher or tertiary education received $13 \%$ of the $8.4 \%$ the Bank allocated for new loan commitments for education. The percentage allocated fluctuates from year to year, due in part to the many factors that play a role in the disbursement of Bank loans. These factors include a country's need or willingness to participate, as well as influential donor countries that may contribute restricted dollars for the World Bank to use. This complex puzzle yields different results each year; for example, Fig. 3 shows the variance in overall education lending allocated to higher education over a 16-year period. 
WORLD BANK LENDING 1963-2006

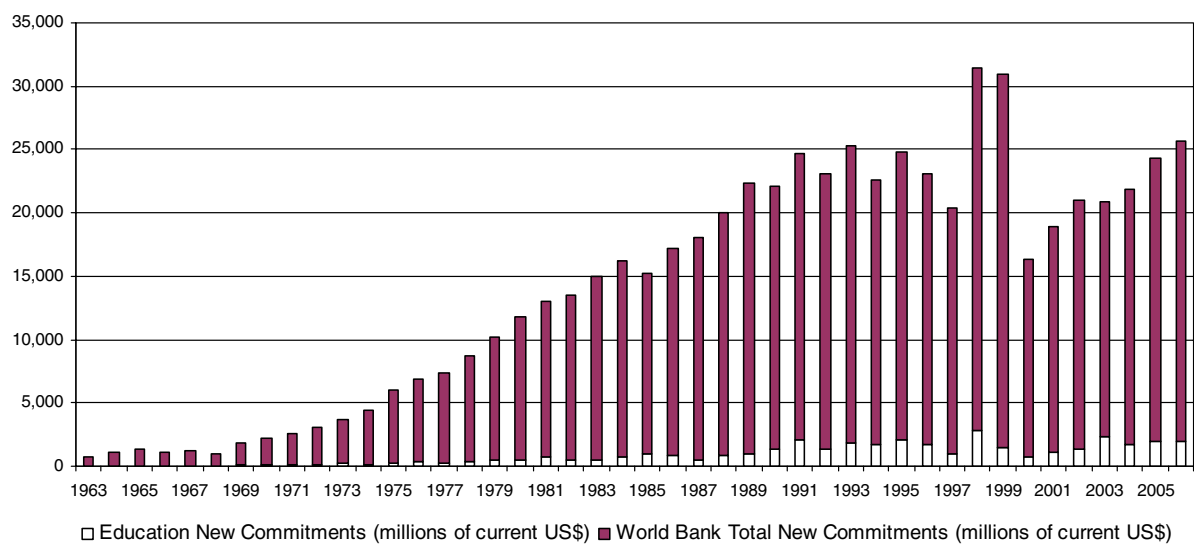

Fig. 1 World Bank lending 1963-2006. Source: these current dollar loan amounts are reported by the World Bank and are available at http://go.worldbank.org/4H9D7XN5E0

\section{LENDING FOR EDUCATION SUB-SECTORS IN 2006}

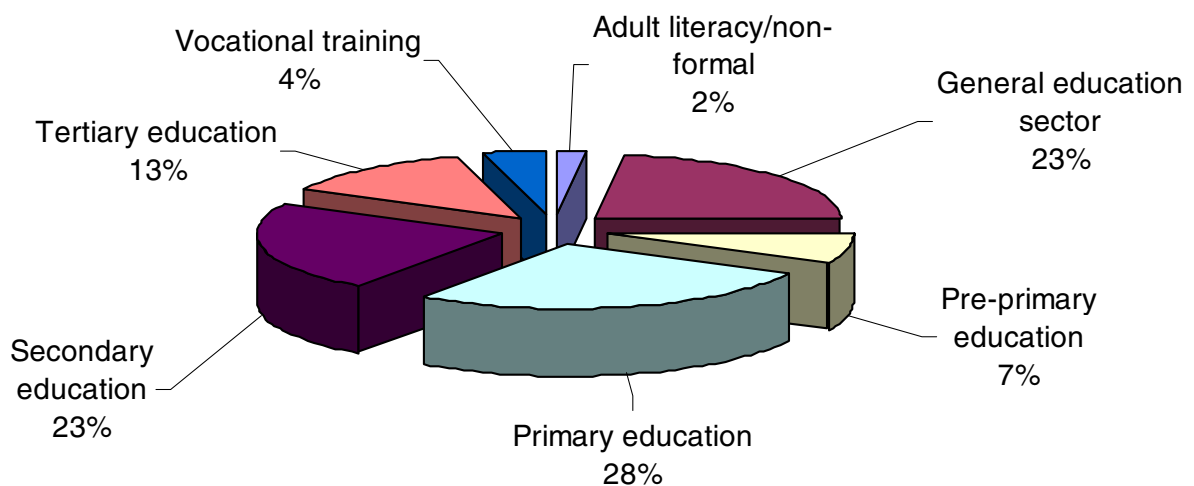

Fig. 2 Lending for education sub-sectors in 2006. Source: data available at http://go.worldbank.org/ 4H9D7XN5E0

A country's willingness to borrow and the Bank's assessment of its ability to repay are important factors in the loan disbursement process. However, when it comes to higher education, the Bank's willingness has played a significant role. George Psacharopoulos, a key World Bank economist, repeatedly found with rate-of return (ROR) analysis that primary education was a better investment than secondary or higher education, based on the fact that unit costs for primary education are small relative to the extra lifetime income or productivity associated with literacy (Psacharopoulos 1981, 1987, 1988, 1996, 2004, 2006). With regard to higher or tertiary education, Psacharopoulos (1988) concluded the opposite to be the case-meaning that unit costs are high relative to the extra lifetime income.

As a consequence of increased recognition of the complexities of higher education's contribution to national development, the Bank eventually moved away from the influential work of Psacharopoulos. Growing support for funding the sector was evident in two key 
PERCENT OF HIGHER EDUCATION LENDING OF TOTAL

EDUCATION LENDING

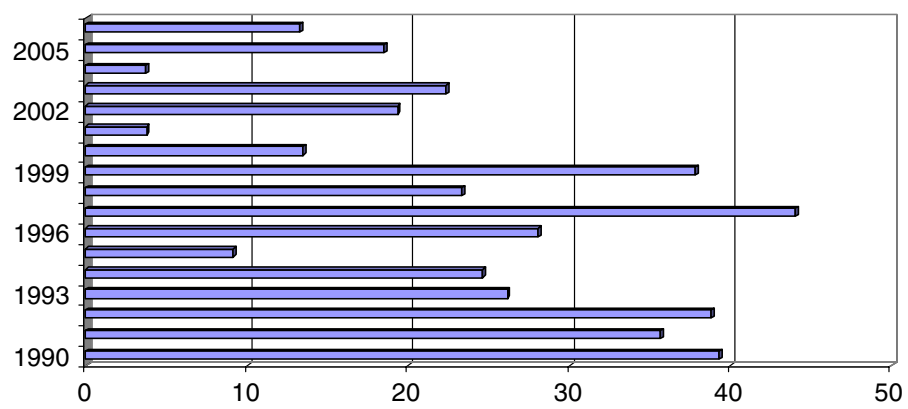

Fig. 3 Percent of higher education lending of total education lending. Source: data available at http://go.worldbank.org/4H9D7XN5E0

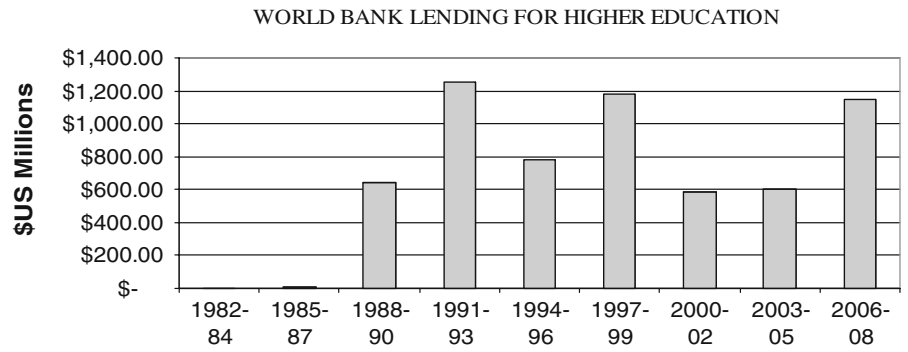

Fig. 4 World Bank lending for higher education. Source: The World Bank projects page, located on their website (www.worldbank.org), lists all of the loans that have been made for the theme, "education and the knowledge economy." This chart is the result of analyzing over 300 loans listed under this theme and extracting the percentage of each loan dedicated to higher education. While there are other types of postsecondary education funding (e.g., vocational education) this chart exclusively displays loans in current dollars for higher education relative to the improvement of colleges and universities

World Bank publications: the 2000 Higher Education in Developing Countries: Peril and Promise produced by the Task Force on Higher Education and Society (TFHES) and the 2002 Constructing Knowledge Societies: New Challenges for Tertiary Education. These reports show how the Bank essentially shifted its discourse about higher education. The shift represents a more sophisticated analysis of the utility of higher education to a nation's economic development. This more recent position of the Bank suggests that commitments to new programs for higher education in developing countries should neither be discounted nor accepted uncritically. As evidence, the TFHES report concluded, "Without more and better higher education, developing countries will find it increasingly difficult to benefit from the global knowledge-based economy" (2000, p. 9). Figure 4 highlights the Bank's significant increase in loan projects and amounts for higher education since the early 1980s in current dollars. Prior to the 1980s there was no funding allocated for higher education.

Although higher education represents a small portion of the overall Bank lending, a significant increase is evidenced over the last few years. In reference to allocated dollar amounts, the shift is positive; however, the larger environment in which lending occurs speaks to deeper issues of ideology. Given the size and complexity of the Bank, it is difficult to identify ideological underpinnings, and competing perspectives are often at 
work. But ideology is clearly a factor in how policies are formed and projects come to be funded. Empirical research may influence policy decisions as well, but research also can be selectively structured so as to produce predetermined results and thus support ideologically driven positions. One Bank official's comments support such a view:

You have to understand one thing and that is that research at a public institution, including most government research, or World Bank research, is strategic in its orientation. An institution does not engage in research for research sake; it engages in research because it has a strategic interest in the outcome. And very often we already know the outcome and what we do is use this research to generate what we want. So it is not true that research results lead to better operations or management...In order to lend in areas where we currently do not, we generate the kind of research that will justify doing what we want to do.

In what appears to be a shift in practice from placing low value on higher education to placing high value, the question of ideology is of central importance in evaluating the work of the Bank.

One hint of the Bank's ideological stance with regard to higher education has been its tendency to push for strengthening the private sector, corresponding with a dismantling of the public sector. Emphasis on the private sector typically is achieved through the enforcement of conditions placed on loans to developing countries. Loans granted through Structural Adjustment Programs (SAPs) have been given on the condition that developing countries substantially decrease funding to all public sector services, with special emphasis on higher education, given past ROR analyzes. One Bank official spoke quite openly about how ideology plays out in such processes: "In higher education, we occasionally put in ideologically driven conditions which have to do with radically shifting the cost of education from the public to the private sectors." Privatization of public services is seen to go hand-in-hand with market liberalization. For example, in a structural adjustment loan to Uganda in 1994 for \$US 80 million, the loan objectives included the "deregulation of the economy involving the removal of the remaining barriers to trade...liberalization of the cotton industry...downsizing the civil service and raising its efficiency" (World Bank 1997, p. 2).

Heyneman, a former World Bank executive, cited three common Bank recommendations often presented as conditions to a loan: (1) shift public expenditures away from vocational and higher education toward academic and basic education; (2) increase the private cost for attending universities; and (3) install loan schemes to set off the financial burden on individuals who must now face high tuition increases for higher education (2003, p. 325). Conditionalities are often disputed, but extensive conditions are consistently found in loan agreements (Eurodad 2006). For example, one Bank official pointed out that conditionality refers to "structural adjustment loans that were made in the 1980s" while another Bank official added that "we never talk about conditions anymore;" rather, they are called "prior actions." The latter term refers to the actions a government needs to take before moving forward with loan procurement. Although there may be disputes about whether "conditions" are still attached to loans or not, comments from Bank officials suggest that the practice of using conditions, regardless of what they are called, exists in some form as a method for the Bank to achieve certain goals.

Debates about the benefits of funding higher education often resurface at the Bank. For example, in March 2008 the Bank published a working paper titled, "Can Cost-Benefit Analysis Guide Education in Developing Countries?" In the paper, Emmanuel Jiminez and Harry Patrinos (2008) return to human capital theory, individual benefits, cost benefits analysis (CBA), and ultimately ROR. This paper acknowledges that while there have been 
some methodological shortcomings to cost benefit analysis, such as the complexity of estimating social benefits, ultimately CBA should be used to guide public investment.

The argument put forth by Jiminez and Patrinos (2008) is quite nuanced and highlights the complexity of measuring externalities of education beyond individual earnings; they even cite researchers who argue that social rates of return, based on creative calculations of externalities, might be higher than individual rates. For example, Wolfe and Samuel (1997) argued that social rates of return are as much as double private rates of return, when calculating nonmarket benefits like health, technological change, crime reduction, and political participation. Ultimately, however, Jiminez and Patrinos (2008) argued that there is not enough information about externalities that can lead to conclusive policy analysis. Hence, their position tends to support that of Psacharopoulos and reasserts the view that higher education should not be a funding priority.

Many of the Bank officials with whom we spoke though tended to see strengthening higher education as a key strategy of poverty reduction. For example, when World Bank education officials were asked directly about how higher education is connected to the broad mission of reducing poverty, they spoke of complex and indirect links.

Obviously the link isn't tight, but in the end you can only reduce poverty by finding ways to increase economic growth and then of course how you distribute benefits from growth. As we moved into the twenty-first century in the context of globalization, global labor markets, global competitiveness, the race toward cost-efficient productivity-higher education has become increasingly important. It is not for nothing that we call it a knowledge economy.

This response links higher education to poverty reduction in terms of its role in supporting the knowledge economy. This official went on to note, "In Africa you find among the very lowest [university] enrollment ratios anywhere in the world. I don't know what the right proportion is, but it has got to be more than 1 or $2 \%$. You cannot run a competitive economy in the world with that few [university] graduates." If a country cannot be an active participant in the global economy with such few college graduates, it seems reasonable to assess the importance of higher education as a development strategy.

Another tension that surfaced in the interviews relates to divergent positions on whether focusing on economic growth is the most effective way to reduce poverty. The point of view favoring economic growth as a vital strategy tended to reflect a neoliberal stance, where the goal is to strengthen free-market practices and encourage privatization. A World Bank economist noted,

In all projects we have this tension between the objective of stimulating growth and fighting poverty. It is not always obvious that growth will reduce poverty. The Latin American countries got growing again and everyone was fine and happy, but when you measure poverty and inequity in those countries it shows that you have growing inequities. Even the most successful case, in Chile, you have growing poverty.

This economist's insight, and the research to which he referred, highlight the fact that some of the positions (e.g., the neoliberalist position) for which the Bank is criticized, sometimes are acknowledged internally. Although critical voices may exist within the Bank, the question that must be asked is whether such voices actually contribute to shifts in policy making and whether there is any recognition of missteps taken in following the narrow logic of neoliberalism.

Nearly all the World Bank officials involved in interviews were quite reluctant to note past Bank mistakes. Indeed, an important theme that emerged from the interviews was a 
sentiment that reduced the Bank's ability to enforce policies. Inability to enforce policies reduces responsibility, and in some cases, culpability for potentially producing negative outcomes. As one Bank official explained:

One of the biggest mistakes I think that observers of international institutions make, especially in terms of the Bank and the Fund, is overstating, overestimating the influence of the Bank. Our mandate requires us to work with the government as it should and that defines what we can do. That is a very complicated relationship, but in many cases we are not as free to impose solutions good or bad as it is thought we are.

It is certainly the case that the World Bank is a complicated organization. Its constituencies include both donor and borrower countries. As the donor community also extends beyond nations to include foundations, each role player contributes to the complexity of the lending process. Furthermore, as every country is very different, it is necessary to have a nuanced approach to lending and development for each additional set of geo-political circumstances. Pointing to such organizational and geo-political complexities to note the Bank's limited reach is somewhat contradictory though, when these same officials spoke of the Bank's important role and their personal and professional commitment to solving world poverty. One cannot claim, on the one hand, to be engaged in important work committed to addressing global poverty, and then, on the other hand, deny responsibility for negative outcomes because the process is so complex.

Other Bank officials also seemed intent on denying the Bank's influence. As another Bank official noted, "This is a place in which the perception of the influence of the Bank far outstrips the reality. The Bank has no police unit. It has no enforcement mechanism. You have to keep that in mind." As we analyzed interview responses such as the preceding, we remained ever cognizant that the World Bank uses US\$24 billion a year to lend to countries in need, but also to set the global development agenda. With an army of economists and a history of powerful influence, a discourse that seeks to portray the institution as less capable than it is may be interpreted as a responsibility reducing discourse. This type of discourse distances the Bank from being held accountable for negative outcomes. But the Bank's global influence must be understood in terms of both its successes and its failures. Given a history of failing to adequately support higher education, what is clear to us is that the Bank has played a key role in helping to produce the sorry state of affairs that many universities in the developing world now face. The fact is that for many years the Bank followed policies that under-valued the role of higher education in economic development, only later to declare that universities are critical to a nation's participation in the global knowledge economy. Although the Bank has econometricians working on a whole host of complex projects, it strikes us as odd that none are working to calculate the financial damage done to developing nations by under-supporting higher education. Although the higher education systems of developing countries are described as out-of-date, dilapidated, and over-crowded, there is little explanation as to why this is the case, other than the oft-repeated mantra that developing countries suffer from vast amounts of corruption. Policy makers in developing nations, however, do not always buy into the Bank's explanation of their higher education struggles. A former Bank official recalled that in Africa many felt that through structural adjustment lending, "the Bank [was] ordering them to disarm in the field of higher education, so they felt the Bank was being a racist and imperialist institution."

In what could only be described as a brief acknowledgement of the harmful practices of the past, a report co-sponsored by the Bank stated that ROR practices were "narrow and misleading" (World Bank 2000, p. 10). As there is no focused accounting of countries in 
which the university system was disrupted or damaged, there is no compelling evidence for the Bank to repair damage that had been previously inflicted. The discourse may not be calculated, but the responsibility-reducing mantra certainly avoids accountability for redressing these prior actions.

Despite previous policy mistakes, the Bank now seems cognizant of the role universities play in a nation's economic development and is in a phase of offering funds to support higher education projects. But greater details are needed about particular projects and how officials within developing nations understand the Bank's engagement in the higher education arena. For example, what are the primary objectives of World Bank support for universities in developing nations? Do Bank officials perceive the goals of higher education funding in a manner consistent with officials in borrower nations? Is the broader "public good" a consideration of Bank higher education projects, or are they mostly directed toward privatization of universities and their "commodities"? We know that in many wealthy nations university knowledge production has become market-oriented and slanted toward fields that have revenue-generating potential. Slaughter and Leslie (1997) defined this trend as "academic capitalism," an idea that later evolved into what Slaughter and Rhoades (2004) called the "academic capitalist knowledge regime." In general, academic capitalism may be understood as "knowledge privatization and profit taking in which institutions, inventor faculty, and corporations have claims that come before those of the public. Public interest in science goods are subsumed in the increased growth expected from a strong economy" (2004, p. 29). Whether or not the Bank's interest in higher education, human capacity building, and knowledge production are driven by a "public good" regime, as opposed to the academic capitalist version, should be a point of concern. The public good regime includes an element that sees universities as institutions that prepare citizens for public life, including public service. The idea of the broad mission of the university, including responsibilities toward developing knowledgeable citizens and making significant contributions to the public good, is important to consider as we examine the Bank's projects in Uganda and Thailand.

\section{The case of Uganda}

The present state of affairs in Uganda is shaped to a great extent by a history of colonialism and the struggle for independence and economic survival. This has necessitated pursuit of financial support from global lenders such as the World Bank, resulting in Uganda falling under the influence of SAPs. Indeed, agreement to adhere to SAPs in the late 1980s made the World Bank "the single most important actor defining the parameters of policy-making in the field of education" in Uganda (Mamdani 2007, p. 10). As a powerful creditor to a country in need, the Bank was able to require stringent conditions without assuming responsibility for failed policies and subsequent consequences (Mamdani 2007). The Bank's conditions led to an increase in funding for primary education and a decrease in funding for higher education. This decision was based on a series of policy papers put forth by the World Bank (1986) and Psacharopoulos (1981, 1987, 1988), arguing that the rate of return on investment was better for primary education than for higher education. Based on such thinking, and paired with claims that higher education lacked equity, the Bank succeeded in influencing the shift in funding in Uganda. The Bank also recommended the decentralization, privatization, and commercialization of higher education, so that income generation, cost sharing, and greater democratization would be achieved at the university level (Mamdani 2007). According to Samoff and Carrol (2003), “There is substantial 
congruity between World Bank recommendations and policies and practices in Uganda" (p. 24). This gives some indication that the Bank's directives have in fact been followed and have helped to shape Ugandan higher education.

Through SAPs and loan conditions, the World Bank had a significant impact on Uganda's system of higher education during the 1980s and early 1990s. These conditions and reforms presented significant challenges for those affected. A mathematics professor at Makerere University, the oldest and most prestigious university in Uganda, recounted the challenges:

This was quite painful because of the reforms of adjusting exchange rates, improving outside administration, and introducing liberalization in a number of sectors. But really, I was so much taken up with my work as a university teacher that I never gave it much thought until I began to see what this meant in terms of the shillings in my pocket. Life was pretty rough in those days. The reform program in place meant that as a public servant, my take-home was very insignificant. Initially, I was rearing chickens to make ends meet. I did this up in my flat at the university because I was pretty desperate at that time to be able to raise money to look after myself and my family. It meant that I needed to go into that kind of business. So I made some money rearing chickens and selling them.

Such comments are consistent with research from Musisi and Muwanga (2001) who reported that Ugandan higher education has been in a state of crisis; they noted that inadequate funding and the concomitant poor conditions of Ugandan universities contribute to inadequate learning and frequent student and faculty strikes.

Other professors and higher education officials from the Ministry of Education (MOE) and the Uganda National Council for Higher Education (UNCHE) also cited World Bank reform initiatives as primary causes in weakening the nation's higher education sector. One MOE official noted that upon approaching the World Bank for funds to support higher education during the period of heavy structural adjustment, he was told that they were interested in primary education, as higher education only poses a benefit for those who obtain it. He said that this position was "forced on the government and the portion of the budget was unfair to higher education." Another explained the problem this way:

What made higher education suffer in the 1980s was the World Bank policy that regarded the cost benefit analysis of basic education as much higher than that of higher education. But now they are saying that higher education is very good for national development. When they were saying that we should put more in primary education, basic education, higher education was getting very little. My feeling is that this higher education problem is one the World Bank caused for us and then backed off afterwards. You cannot survive on basic education alone in a developing society, because we know that in higher education we find invention and creationwe know that.

Although views of the current role of the World Bank differed, we observed a fairly consistent response in terms of the World Bank's influence during the time of SAPs and their impact on higher education. Almost everyone with whom we spoke expressed that Bank policies had had quite a negative impact on universities and that they still had not recovered from the period of structural adjustment.

As an indication of the change in policy leading to greater support for higher education, one Ugandan scientist described a relatively recent Bank loan-the Millennium Science Initiative (MSI) — as a "significant departure" from the activities of the past. The initiative, 
approved in 2006, has devoted US\$ 30 million to advance primary objectives aligned with Uganda's own poverty eradication plan. One loan objective calls for the improvement of human development by reforming higher education programs to include a greater emphasis on science and technology (World Bank 2006, pp. 4-5). The loan provides a tangible representation of the Bank's more recent policy direction in higher education (World Bank 2000, 2002). The project aims to produce a greater volume of high performing science and engineering graduates, as well as high quality relevant research. The MSI is part of the larger landscape of lending to Uganda, which includes almost \$US 200 million in 2004 to \$US 540 million in 2007 in current dollars. Given the high volume flow of money, as well as the size and variety of projects, the work of the Bank has produced an assortment of opinions.

Generally speaking, the current work of the Bank produced two divergent views in Uganda among Ministry of Education officials, professors, and others having direct involvement with World Bank lending. One camp was more concerned with the ideological underpinnings of the Bank and spoke of Uganda's ongoing dependency. These individuals used terms such as "colonialism" or "neocolonialism" to describe the nature of the Bank's involvement in their country. A second camp expressed more of a neutral to slightly positive stance toward the Bank's support and tended to believe that the Bank was reforming its ways. These individuals saw the MSI as a tangible example of the Bank's renewed commitment to higher education in Uganda.

The group critical of the World Bank spoke of ideological considerations that connected present-day policies of the Bank to past actions. They tended to focus on three areas of criticism: poor alignment of Bank policies with governmental goals, harsh conditionalities imposed by the Bank, and a tendency to support policies that increased Uganda's dependency. In reference to the criticism of poor alignment, a professor and educational management researcher commented that, "In most cases, the World Bank's ideas will override those of Uganda. First of all, because Uganda has borrowed money from the World Bank, and it is still in need of money, we have to be flexible in order to access the money." One particular high ranking official within the Ministry of Education took a very critical position about the role of the Bank in this regard: "The World Bank should do one thing if they want to develop in Africa. They should understand the socio-economic sector of society before intervening and should try to appreciate the goals of the society. Some of us believe the World Bank does not want us to develop so they can maintain a market here. They have been here for many years and not much is changing."

A second line of criticism of the Bank focused on the "forcefulness" of loan conditions. For example, during the structural adjustment period in the 1980s the World Bank required that Uganda expand funding for primary education and reduce higher education. One Ministry of Education official recounted that this position seemed "forced on the government and unfair to higher education, because the country was held at ransom." Though the structural adjustment period has ended, this official noted that "the World Bank still requires that primary education has to be at $65 \%$ of the budget and higher education gets between 6 and 9\%. Even if you increase the education budget by a significant amount, higher education only gets a small percentage."

The final area of criticism centered on issues of ongoing dependence and the role of the Bank. This concern is also connected to issues of conditionality. A professor of education offered insight here, alluding to elements of unilateralism that may continue conditions of dependence:

We are in the colonial age. Rather than being taken as a slave physically, we are taken monetarily. The World Bank has put conditions on us that need to be studied, 
but we are desperate-we want to eat. The Bank is saying before you eat the food you must take this and that. We take the food and damn the consequences. On another level, these consequences will tie down generation after generation...You cannot say you develop me. I am the one to develop myself. You can assist me. But to say you are going to develop me, no, that cannot work.

The preceding comment also raises issues relating to development ideology, particularly in regard to Uganda's colonial history and the potential for a neocolonial present and future. A Ministry of Education official working in the commission for higher education similarly commented, "We cannot make an independent policy decision. If we could, we wouldn't really need the money." In regard to imposed policies, another high ranking official in the Ministry of Education stated, "The World Bank is perpetuating colonialism. If you make somebody dependent, the person will never be free, because when I'm dependent on you I must agree with you at all times." Yet another official with the commission for higher education echoed these negative sentiments about the Bank and its role in shaping Uganda:

You cannot develop through aid. We are arguing to the Western world to let us have equal opportunities in trade. We are the donors. Countries in the Western world are not the donors. We are the donors because we are giving our resources for almost nothing to the Western world. They process it and return it to us at almost 10 times the price. When we went to China to sign an agreement between our education ministries for scholarships, they told me to forget it - the World Bank will never let you grow.

The preceding comments reflect a high degree of resentment toward the World Bank and the West in terms of the way development policies have been advanced in Uganda. Those critical of the Bank tend to see such policies as an extension of the colonial era, but through evolving mechanisms such as SAPs and conditionality.

In the second camp were several individuals who saw the Bank in a more neutral or slightly positive way, and who for the most part did not use harsh words in describing present-day Bank policies. While most of these individuals criticized past Bank actions, they tended to believe it had reformed its ways. For example, a scientist involved with the MSI described a visible change in the Bank's operations: "It seems to me there was a tendency in the past to structure projects from the upper echelons of government without the necessary component or contributions from technical people who would eventually have ownership over these projects. And I am saying this because the MSI project that I am involved in had a significant departure from its inception, because now the needs assessment is very indigenous." And another Ugandan scientist identified the MSI as a significant sign of change on the part of the Bank: "The World Bank in the past concentrated more on developmental programs, roads, water, sanitation, and so forth, but now I think a very big challenge to the developmental nature of their mission has come, and that is supporting science and technology development, which breaks down into things like developing human capital, expanding human resources in science, funding for research, and supporting innovation. So this is very rare."

The MSI project components designed to advance academic science and technology are divided into two sections. The first section includes competitively awarded grants to senior researchers, funds for the creation of undergraduate science and engineering programs, and support for private sector cooperation. The second component involves an outreach 
program to enhance public appreciation for science and to help facilitate commercially relevant technology transfer and technology development (World Bank 2006).

Those who adopted a more a neutral or positive tone toward the Bank were quite familiar with the MSI (this is not to say that everyone familiar with the MSI was positive). This lends support to the notion that the MSI represents a new model of lending more beneficial to Ugandan higher education. The functioning of the MSI includes an emphasis on consensus building as opposed to employing a top-down Bank-driven conception of what needs to happen in order to bolster the nation's knowledge development and global participation. Although the emphasis on being commercially relevant offers some indication of the influence and relevance of the academic capitalist knowledge regime, there is also an emphasis on civil society and advancing agendas that will benefit the public good. These are somewhat contradictory findings given the larger climate of neoliberalism at the Bank, as evidenced through years of structural adjustment demands largely focused on privatization and a reduction of funding for public services. Given the Bank's size and scope, understanding these contradictions may shed light on the challenges of reframing its policies and course of action.

In developing countries like Uganda, there is a struggle about where to allocate money in developing human capacity. The basic education and rate of return analysis debate is still alive there because of limited resources. University education, and especially research, is certainly more expensive than basic education, which is why there is much value in explaining the connections between university research in science and technology and human capacity building and poverty reduction. One scientist in Uganda offered this explanation:

Research is expensive, but as a scientist, I've always told colleagues that it's very, very dangerous for you to do a cost-benefit analysis for research because you may never do the research. For example in Uganda, we have a coffee variety that was developed in the late 1960s. Now every homestead has this coffee, so who made those projections then? As this was being developed, a lot of money went into the lab for the research. That is just coffee, but let's talk of a vaccine. There is a lot of research and a lot of money to develop vaccines for HIV/AIDS, but once a breakthrough comes the impact will be felt for generations. So if you do a cost-benefit analysis and you start seeing we are spending $\$ 50$ million on this project, and that $\$ 50$ million is potentially going to contribute to curing AIDS and will save millions of lives, then you can understand. So I've always discouraged people that want to do a cost-benefit analysis.

The MSI is seen as a concrete example of the Bank's shift toward supporting university education and research. It is, however, interesting to see the work of the Bank persist in this environment, with no acknowledgment that SAPs may have contributed to some of Uganda's serious problems. This institutional amnesia may be linked to neocolonial sentiments.

Many of Uganda's present-day struggles can be understood in the context of colonialism and neocolonialism. In this era following formal colonialism, tribal conflicts persist between northern and southern Uganda, and neighboring countries, like Congo, experience relentless war and genocide. Easterly (2006) wrote that, "Colonialists left behind independent states with arbitrary borders that had little chance to build up popular legitimacy... it was not surprising that most of these new states were unfriendly to both economic and political freedoms" (p. 272). The colonial effects seem to have created a ripe environment for neocolonial policies involving structural adjustment programs and harsh conditionalities. In the case of Uganda, the impact of past colonialism has been referred to by officials 
as at least one reason for the existing political and economic turmoil. This turmoil has fostered increased dependency, which some officials linked to the nation's willingness to accept the negative conditions of Bank loans. Colonial occupation has indeed ended, but in its place now exist economic dependence and a lack of political autonomy. This essentially amounts to neocolonialism, a point noted by several professors and higher education officials and revealed in comments about Uganda being "needy," "dependent," "desperate," and subject to "monetary slavery," and hence having little choice but to go along with development prescriptions from IGOs like the World Bank.

\section{The case of Thailand}

Thailand borrowed from the World Bank for the first time in 1950. Three loans were procured to enhance railways, ports, and irrigation systems. Since then, Thailand has borrowed a total of \$US 7.7 billion, including two structural adjustment loans in the 1980s. These loans incorporated the typical formula for structural adjustment, including deregulation, decreasing taxes, and decreasing public expenditures. In terms of the structural adjustment era, there is not a great sense that the World Bank had a negative impact on higher education in Thailand, especially when compared to the case of Uganda. Rather, most policy makers and faculty with whom we spoke presented a consistent theme of partnership with the World Bank. It is also important to note that Thailand has been much more resistant to borrow than Uganda. One Bank official in Thailand elaborated, "10 years ago, the Bank had lots of education projects in Thailand. It was very active. But not today. And it is not necessarily a reflection of the Bank's own thinking about education, but it's a reflection of Thailand's own thinking as to education and the role of the Bank and what the role of the Bank is or will not be." This Bank official also added that in terms of influence, the Bank has the "bully pulpit," particularly in terms of research they provide to Thailand.

In terms of financial arrangements, the Bank presently has a very small portfolio in Thailand and no lending program in education. Since the completion of a Bank loan to enhance undergraduate science and engineering in 2003, there has been little discussion about another loan project. The volume of lending in Thailand came to around \$US 80 million in 2004, and has been nonexistent since then. It appears that the Thai government has taken on a new perspective concerning debt and development practices of the Bank.

In our research about the influence of the Bank on higher education in Thailand, it is important to highlight two key findings. The first finding addresses the impact of the most recent loan for science and engineering as an indicator of the World Bank's work in higher education. The second finding relates to curriculum and national self-perception in Thailand, surrounding what many officials referred to as the King's plan for a sufficient economy. We found the latter point to be a significant aspect of higher education policy making, as the Ministry of Education and key decision makers shape school and university curriculum and the country's relationship with the Bank.

Although Thailand's borrowing history includes some US\$ 6 million for vocational education beginning in 1966 (until the late 1980s and early 1990s the Bank's involvement in higher education was mostly in the area of vocational education), we chose to focus on more recent loans reflective of the Bank's policy shift toward greater support for higher education. In terms of the most recent loan to support science and engineering, mostly positive outcomes were reported by university personnel. Some negative residue resulting from conditionality and equipment procurement processes also were noted. 
The Universities Science and Engineering Education Project (USEEP) represents the Bank's commitment toward advancing Thai universities and their ability to contribute to the knowledge economy. Completed in 2003, the project supported enhancements at 20 public universities. The loan was meant to strengthen the teaching capabilities of the faculty, upgrade the content of existing science and engineering programs, broaden the number of programs relevant to Thailand's technological advancement, and procure large quantities of major laboratory equipment to modernize laboratories (World Bank 2004). The report evaluating the completion of the project identified that the project met and even exceeded its objectives. In stating our desire to evaluate the impact of the loan, officials from the Bank office in Thailand were skeptical that university departments benefiting from the loan would be aware of the Bank's role. However, we found that each department receiving support knew exactly what equipment was received as a result of the project. Some departments even kept quite elaborate usage charts to assess how often the equipment was utilized.

Although grateful for the research equipment, some university departments found that they did not get the equipment they requested. For example, when a department ordered engineering microscopes yet received biology microscopes, the equipment had to be modified to work in their labs. Other faculty members directed us to very expensive prototyping equipment that had to be purchased from companies that did not offer a service plan. The equipment no longer works and there is no provision for fixing the equipment. In response to questions about such equipment, officials involved in procuring the loan from the Commission of Higher Education explained, "The World Bank required the purchase of any equipment over 1 million Thai baht to follow an international bidding process. This was a condition." Consequently, in some cases incompatible and/or unsustainable equipment became a byproduct of such conditions. However, the extent of this problem is not entirely clear as the state of the current usability of equipment is not covered in any of the accessible assessment reports. Although the whole of the project demonstrates concrete support for the Bank's claims to a higher education policy shift, it also shows some negative residue of loan conditions that are not calibrated to produce the best outcomes. The issue of incompatible or unsustainable equipment as a result of loan conditions appeared to be something of which Bank officials involved in the loan were unaware.

In general, the Thai Ministry of Education officials and faculty portrayed a mostly neutral attitude toward the World Bank and its impact on higher education in their country. With reference mostly to the USEEP, they saw both positive and negative outcomes. In general, they did not elucidate the type of criticism exhibited in Uganda. However, Thailand has largely moved away from borrowing from the Bank. One education official stated that they borrow some money from the Asian Development Bank, as loans do not include such stringent conditions. This official indicated that such loans tend to include longer grace periods and lower interest rates.

The fact that Thai officials preferred to move away from World Bank involvement is suggestive of a key second finding in our study, pertaining to what was described as the "King's sufficient economy"; every conversation we had with members of the Ministry of Education and the Commission of Higher Education referenced the nation's commitment to the King's sufficient economy. In response to the economic crisis in 1997, King Bhumibol suggested that greed accompanies orthodox capitalism, of which the IMF was seen to be a primary advocate. According to King Bhumibol, the country could have avoided the crisis if it had followed his economic outlook. As he put it, "To become a tiger [economically speaking] is not important. The important thing is for us to have a selfsupporting economy. A self-supporting economy means to have enough to survive. Each 
village or each district must have relative self-sufficiency" (Handley 2006, p. 414). A Thai Ministry of Education official elaborated as well:

The Thai principles are to be good, be happy, be academically excellent. Every college and university has to emphasize this in activities and in education. It is an opportunity to bring the King's philosophy about the sufficient economy into the curriculum. The ministry has now implemented this curriculum and added a course on sufficient economy to the university. We must protect ourselves from being destroyed by money. The hard thing is how do we emphasize or make sure the students can achieve the philosophy of the King.

The value of this idea of sufficiency is relevant within the discussion of colonialism, dependence, and development. Thailand is a relatively homogenous country (e.g., it is $98 \%$ Buddhist) and it is culturally taboo to speak negatively about the religio-apolitical function of the King. Thailand has a history of avoiding colonialism, and the economic crisis in the late 1990s was largely billed as a result of becoming too dependent on development agencies like the IMF (Jansen 2002). This crisis now serves as an example within the self-sufficiency rhetoric to avoid any potential neocolonial burden resulting from dependency. This represents a stark difference from Uganda's colonial history and the current view that neocolonialism is pervasively manifested through dependence on IGOs like the World Bank.

There is no indication that Thailand will request loans from the Bank in the near future. In the meantime, the Bank maintains a presence in the country by offering its services as a knowledge bank, which essentially amounts to providing research and knowledge of best practices. Overall, it seems the last higher education loan for strengthening science and engineering was largely successful, in spite of the problems with equipment procurement and maintenance. Finally, an ethos of economic independence is reflected in Thailand's avoidance of debt and loan conditions, a reality made possible to some degree by Thailand's ability to escape colonial domination and the fact that its economic challenges are less severe by comparison to Uganda (as evidence to support the greater economic independence of Thailand, we note that it ranks 75th on the United Nations Human Development Index (HDI) and its national debt at over US\$52 billion is equal to less than half of the GDP, whereas Uganda ranks 144th and its national debt of US\$5 billion is equal to an estimated $64 \%$ of the GDP). Thus, economic independence should be understood as a reflection of both its actual situation relative to other developing nations, as well as by economic ideals associated with the King's sufficient economy.

The Bank's present engagement in Thailand mostly represents its emerging role as a knowledge bank. As a knowledge bank, the Bank not only provides loans but also expertise about development practices. But even in this role the Bank faces its share of criticism, as concerns have emerged about the degree to which congruence exists between Bank recommendations and the practices of developing countries (Samoff and Carrol 2003). A senior official in the Thai ministry of education alluded to the Bank's role as knowledge bank and some of the problems with this role:

It is not uncommon for the World Bank to conduct some research. When they organize their research, they say, "Look, the government of Thailand should do the following with education in order to get this result" and then they will give recommendations. The World Bank will typically mention the problem first, and later they will come and the government of Thailand will set up some committee to consider deeply the recommendation of the World Bank. So we accept their report and we accept their points of view because we often have had trouble conducting analyzes. 
They perform like they are the doctor you see, and when the patient comes, they say,

"Oh you have fever. You have to take this medicine." Our weakness has been that we accept the situation. However, it has been a long time of not proposing a loan project.

The idea of the knowledge bank is to serve as a resource for developing nations, offering research, expertise, and knowledge of best practices. In the case of Thailand, it appears that there is a willingness to draw from that expertise, but perhaps with a healthy level of caution and skepticism by certain segments of the government. In the absence of lending, providing knowledge to Thai officials maintains a modest level of Bank engagement and influence.

\section{Discussion}

Officials in Uganda and Thailand generally hold skeptical views of the World Bank's past work, but most see the present-day policies of the Bank as more supportive of higher education, specifically with regard to increased funding for academic science and technology. The two case studies presented here provide concrete examples of the World Bank's shift in policy and its recognition of the social and economic benefits of higher education beyond the individual benefits measured by narrow rate-of-return analyzes. Given that the loans discussed in this article were meant to support science and technology, the Bank's new commitment toward building a locally relevant knowledge economy is highlighted. The Bank encouraged each respective country to improve its research capacity in order to increase participation in the global economy. While Thailand's loan project is now completed, the project in Uganda is still in its early stages. In this regard, it remains unknown as to whether Uganda will experience the challenges of equipment sustainability and stringent procurement conditions that existed in the Bank's arrangements with Thailand.

Although some specific similarities are revealed in each country's loans, our study also highlights the fact that distinctive views of the World Bank exist among key players in the respective nations. For example, divergent views about the role of the Bank in shaping their nation's universities emerged in Uganda, whereas perspectives about the contribution of the Bank in Thailand were more homogenous and generally more positive. The issue of economic dependence may be the key variable in explaining the different views among Ugandan and Thai officials, as well as among faculty involved in Bank-supported projects and activities. In Uganda, for example, discussions of neocolonialism often accompanied general criticism of the Bank and its neoliberal agenda. It was not unusual for Ugandan officials and faculty to provoke images of hunger and desperation when they spoke of the Bank. They noted the Bank's lack of concern about the consequences of the loans. Such perceptions of the Bank seem fairly congruent with Musazi's (1986) claim that, "dependency and neocolonialism are linked" (p. 325), and that, "African education will come of age only when Africa develops a capacity to innovate independently" (p. 345).

Despite Uganda gaining independence from Britain in 1962, economic independence remains rather elusive. In contrast, a push for economic independence characterizes the state of affairs in Thailand. Whereas dependency, development, and neocolonialism tended to frame the commentary of the more critical Ugandan officials and faculty, conversations about independence and self-sufficiency dominated conversations with Thai policy makers. Of course, the different perspectives represented by officials in these two countries is quite likely due to vastly different economic struggles (the Ugandan economy is in far worse shape than the Thai economy) and a history of colonial domination for one (Uganda) and 
not the other (Thailand). However, Thailand is certainly not without its developmental challenges, particularly with regard to the higher education sector, but such challenges are quite different from the colonial residue and the neocolonial dependency issues characterizing Uganda's context.

These two cases provide insight into differences relating to matters of dependency and colonialism, or neocolonialism specifically in the case of Uganda. In terms of the role of the Bank in potentially perpetuating dependency through new forms of colonialism, we found many Bank officials quite aware of such charges. They were also well prepared to refute them. Many even pointed out that while the Bank may have at one time been guilty of implementing bad policy, those days have since passed. Several noted that tension had existed within the Bank with regard to its developmental policies and programs for years. Of course, the Bank is a large institution with many economists and specialists who do not all think alike. Most Bank officials with whom we spoke seemed quite committed to reducing poverty and certainly did not suggest any ill-will on the Bank's part to further colonial domination. In fact, we found those with whom we interacted to have quite progressive views about education, higher education, and the potential for reform through technical assistance.

However, individual expertise and professional commitment do not negate the function of neoliberal development ideology and the potential detrimental effects of structural changes forced on debtor nations. Some Bank officials recognized the shortcomings of past policies and emphasized that it is difficult to assess when or if the Bank has truly turned the corner. Indeed, one Bank official likened the organization to "the Queen Mary," noting how difficult it is for such a large organization to chart a new course. However, with over 10,000 employees and offices in one hundred countries, a more fitting metaphor than the Queen Mary might be that of a naval fleet or armada. Coordinating so many staff, economists, and experts scattered around the world is difficult to imagine, especially when divergent opinions and viewpoints exist.

In spite of a more positive view of the importance of higher education and more localized forms of knowledge development (no matter how slowly it has come about), contradictions still exist. Some of these contradictions concern matters of responsibility, given that the negative impact of SAPs on higher education is believed to be great by officials in countries such as Uganda. For a Bank that employs thousands of economists, it seems prudent to learn more about how past policies may have debilitated higher education sectors, what the approximate costs to repair them might be, and the degree to which IGOs such as the World Bank ought to take responsibility. For example, decades passed without Bank support for building research capacity in developing nations, based on the conclusion that such nations were too far behind to compete in academic-based knowledge production (Santos 2006). Is it not then reasonable to ask: What are the costs of Bank policies that perpetuated a hierarchical view in terms of which nations can and cannot contribute to the knowledge economy? Key publications from the Bank $(2000,2002)$ highlight the importance of knowledge creation in developing nations, and yet they also fail to identify the ways in which the Bank's own policies contributed to limiting the development of universities.

When criticism of the Bank arose in discussions with Bank officials, many were quick to point out that the Bank is not entirely to blame. In fact, most of the economists and education specialists interviewed at the Bank headquarters in Washington DC highlighted the complexities of working with unstable governments, politically volatile situations, corruption, and so forth. Some Bank officials defended their policies (past and present) and felt that too many, including those in developing nations, are quick to point fingers, when their own actions may also be part of the problem. Indeed, Bank officials working in 
Thailand and Uganda emphasized that their work is in fact shaped by the goals of the respective countries. This point of view of the Bank and its policies was more harshly criticized by Ugandan officials than by those in Thailand.

\section{Conclusion}

Development banks certainly face a difficult task. But despite their challenges, an important question must be asked: Whose version of economic development is to be enacted? The answer seems fairly obvious to us-it is a view of economic development most suitable to the wealthiest nations of the world and consistent with the neoliberal project. Can we truly expect developing nations to compete in a global free market, when wealthy nations such as the United States and Japan built many of their vital industries through protectionist practices? As one such key industry, higher education has finally become an important source of consideration for the Bank and its development strategies. Our study supports the position that the World Bank has shifted its view on higher education and at least recognizes some potential for developing nations such as Uganda and Thailand to produce relevant forms of academic and scientific knowledge; this more recent approach to valuing universities for their research and knowledge production capacities is evident in the Bank's funded programs in the two respective countries. But at the same time, the Bank ignores damage from its past policies and fails to take responsibility for fixing a system it helped to break in the first place.

The fact that neoliberal ideology continues to undergird funding in the developing world, even in the area of support for higher education, suggests to us that policies and practices contributing to asymmetrical relations between wealthy and developing nations continue to exist. Such a reality lends credence to the perspectives of Ugandan officials in particular who argued that new policies and strategies are in place that in the end reproduce relations of dependency and represent new forms of colonialism. Even in Thailand, where greater economic independence exists and a less negative view of the World Bank was expressed, serious concerns led officials to purposely distance the nation from Bank loans and the inevitable conditionalities. Certainly, the preponderance of evidence presented in this paper suggests the duplicity of the World Bank in furthering global inequities. Recent shifts in higher education loan practices are of the size and scope to hardly impact the sizeable problem they helped to create. In this regard, our work tends to support some of the assertions made by critical scholars such Chomsky (1999), Harvey (2003), and Said (1993), and points to the need to hold global development organizations such as the World Bank more accountable, especially in terms of their one-size-fits-all economic ideology and for past damage rendered through faulty policies.

Open Access This article is distributed under the terms of the Creative Commons Attribution Noncommercial License which permits any noncommercial use, distribution, and reproduction in any medium, provided the original author(s) and source are credited.

\section{References}

Alatas, S. F. (1993). On the indigenization of academic discourse. Alternatives, 18, 307-338.

Apple, M. W. (2000). Between neoliberalism and neoconservatism: Education and conservatism in a global context. In N. C. Burbules \& C. A. Torres (Eds.), Globalization and education: Critical perspectives (pp. 57-77). New York: Routledge. 
Arnold, D. O. (1970). Dimensional sampling: An approach for studying a small number of cases. The American Sociologist, 5, 147-150.

Cardoso, F. H. (1977). The consumption of dependency theory. Latin American Research Review, 12(3), 7-24.

Carroll, T. (2006). The World Bank's socio-institutional neoliberalism: A case study from Indonesia. Paper presented at the Workshop on the World Bank, Lee Kwan Yew School of Public Policy, National University of Singapore, 18 September.

Chomsky, N. (1999). Profit over people: Neoliberalism and global order. New York: Seven Stories Press.

Chomsky, N. (2003). Hegemony or survival: America's quest for global dominance. New York: Owl Books.

Creswell, J. (1998). Qualitative inquiry and research design: Choosing among five traditions. Thousand Oaks, CA: Sage.

Easterly, W. (2006). The white man's burden: Why the west's efforts to aid the rest have done so much ill and so little good. New York: Penguin Press.

Eurodad. (2006). World Bank and IMF conditionality: A development injustice. Retrieved 10 November 2006 from: http://www.eurodad.org/articles/default.aspx?id=711.

Frank, A. G. (1967). Capitalism and underdevelopment in Latin America: Historical studies of Chile and Brazil. New York: Monthly Review Press.

Geiger, R. L. (1986). To advance knowledge: The growth of American research universities, 1900-1940. New York: Oxford University Press.

Geiger, R. L. (1993). Research and relevant knowledge: American research universities since World War II. New York: Oxford University Press.

Goldman, M. (2005). Imperial nature: The World Bank and struggles for social justice in the age of globalization. New Haven: Yale University Press.

Hall, S., \& Jacques, M. (1990). Introduction. In S. Hall \& M. Jacques (Eds.), New times: The changing face of politics in the 1990s (pp. 11-20). London: Verso.

Handley, P. M. (2006). The king never smiles. New Haven: Yale University Press.

Harvey, D. (2003). The new imperialism. Oxford: Oxford University Press.

Heyneman, S. P. (2003). The history and problems in the making of education policy at the World Bank 1960-2000. International Journal of Educational Development, 23(3), 315-337. doi:10.1016/S07380593(02)00053-6.

Jansen, K. (2002). Thailand: The making of a miracle? Development and Change, 32(3), 343-370.

Jiminez, E., \& Patrinos, H. A. (2008). "Can cost-benefit analysis guide education policy in developing countries?” Policy Research Working Paper 4568. Washington, DC: The World Bank.

Larrain, J. (1989). Theories of development: Capitalism, colonialism and dependency. Cambridge, UK: Polity Press.

Mamdani, M. (2007). Scholars in the marketplace: The dilemmas of neo-liberal reform at Makerere University, 1989-2005. Kampala, Uganda: Fountain Publishers.

Maxwell, J. (1996). Qualitative research design: An interactive approach. Thousand Oaks, CA: Sage.

Morrow, R., \& Torres, C. A. (2000). The state, globalization, and educational policy. In N. C. Burbules \& C. A. Torres (Eds.), Globalization and education: Critical perspectives (pp. 27-56). New York: Routledge.

Musazi, J. C. S. (1986). Planning and development in education: African perspectives. London: Allen and Unwin.

Musisi, N. B., \& Muwanga, N. K. (2001). Makerere University in transition, 1993-2000: Opportunities and challenges. Makerere University, Makerere Institute of Social Research: Kampala.

Ordorika, I., \& Pusser, B. (2007). La máxima casa de estudios: The Universidad Nacional Autonoma de Mexico as a state-building university. In P. G. Altbach \& J. Balán (Eds.), Empires of knowledge and development: The roles of research universities in developing countries. Baltimore, MD: Johns Hopkins University Press.

Peet, R. (2003). Unholy trinity: The IMF, World Bank, and TWO. London: Zed Books.

Peters, M. A., \& Besley, A. C. Tina. (2006). Building knowledge cultures: Education and development in the age of knowledge capitalism. London: Rowman \& Littlefield Publishers.

Prebisch, R. (1984). Five stages in my thinking on development. In G. M. Meier \& D. Seers (Eds.), Pioneers in development (pp. 173-191). New York: Oxford University Press.

Psacharopoulos, G. (1981). The World Bank in the world of education: Some policy changes some remnants. Comparative Education, 17(2), 141-145. doi:10.1080/0305006810170204.

Psacharopoulos, G. (1987). Economics of education: Research and studies. Oxford: Pergamon Press.

Psacharopoulos, G. (1988). Education and development: A review. Research Observer, 3(1), 99-116. doi: 10.1093/wbro/3.1.99.

Psacharopoulos, G. (1996). Public spending on higher education in developing countries: Too much rather than too little. Economics of Education Review, 15(4), 421-422. doi:10.1016/S0272-7757(96)00024-6. 
Psacharopoulos, G. (2004). Moderated discussion: The task force on higher education and society. Comparative Education Review, 48(1), 84-85.

Psacharopoulos, G. (2006). World Bank policy on education: A personal account. International Journal of Educational Development, 26, 329-338. doi:10.1016/j.ijedudev.2005.09.001.

Pusser, B. (2006). Reconsidering higher education and the public good: The role of public spheres. In W. G. Tierney (Ed.), Governance and the public good (pp. 11-27). Albany, NY: State University of New York Press.

Rhoads, R. A., \& Torres, C. A. (2006a). The global economy, the state, social movements, and the university: Concluding remarks and an agenda for action. In R. A. Rhoads \& C. A. Torres (Eds.), The university, state, and market: The political economy of globalization in the Americas (pp. 321-351). Stanford: Stanford University Press.

Rhoads, R. A., \& Torres, C. A. (Eds.). (2006b). The university, state, and market: The political economy of globalization in the Americas. Stanford: Stanford University Press.

Said, E. W. (1993). Culture and imperialism. New York: Vintage Books.

Samoff, J., \& Carrol, B. (2003). From manpower planning to the knowledge era: World Bank policies on higher education in Africa. UNESCO forum on Higher Education Research and Knowledge.

Santos, B.d. S. (2006). The university in the 21 st Century: Toward a democratic and emancipatory university reform. In R. A. Rhoads \& C. A. Torres (Eds.), The university, state, and market: The political economy of globalization in the Americas (pp. 60-100). Stanford: Stanford University Press.

Sidhu, R. (2007). GATS and the new developmentalism: Governing transnational education. Comparative Education Review, 51(2), 203-227. doi:10.1086/512020.

Slaughter, S., \& Leslie, L. L. (1997). Academic capitalism: Politics, policies, and the entrepreneurial university. Baltimore, MD: Johns Hopkins University Press.

Slaughter, S., \& Rhoades, G. (2004). Academic capitalism and the new economy: Markets, state and higher education. Baltimore, MD: Johns Hopkins University Press.

Stiglitz, J. E. (2002). Globalization and its discontents. New York: W. W. Norton \& Company.

Torres, C. A., \& Rhoads, R. A. (2006). Introduction: Globalization and higher education in the Americas. In R. A. Rhoads \& C. A. Torres (Eds.), The university, state, and market: The political economy of globalization in the Americas (pp. 3-38). Stanford: Stanford University Press.

Wallerstein, I. (1979). The capitalist world-economy. Cambridge: Cambridge University Press.

Wallerstein, I. (2004). World-systems analysis: An introduction. Durham, NC: Duke University Press.

Wolfe, B., \& Samuel, Z. (1997). Non-market effects of education. International Journal of Educational Research, 27(6), 491-502.

World Bank. (1986). Financing education in developing countries: An exploration of policy options. Washington, DC: The World Bank.

World Bank. (1997). Uganda structural adjustment credit: Project information document. Retrieved 5 November 2006 from http://web.worldbank.org/external/projects Washington, DC: The World Bank.

World Bank. (2000). Higher education in developing countries: Peril and promise. Washington, DC: The World Bank.

World Bank. (2002). Constructing knowledge societies: New challenges for tertiary education. Washington, DC: The World Bank.

World Bank. (2004). Thailand universities science and engineering project: Implementation Completion and results report. Retrieved 5 November 2006 from: http://web.worldbank.org/external/projects Washington, DC: The World Bank.

World Bank. (2006). Uganda millennium science initiative: Project information document. Retrieved 5 November 2006 from: http://web.worldbank.org/external/projects. Washington, DC: The World Bank.

Yin, R. (1989). Case study research: Design and methods (rev. ed.). Newbury Park, CA: Sage. 